Marquette University

e-Publications@Marquette

Biomedical Engineering Faculty Research and

Publications

Biomedical Engineering, Department of

$2-2008$

\title{
Leg Sympathetic Response to Noxious Skin Stimuli is Similar in High and Low Level Human Spinal Cord Injury
}

M. Kevin Garrison

University of Central Arkansas

Alexander V. Ng

Marquette University, alexander.ng@marquette.edu

Brian D. Schmit

Marquette University, brian.schmit@marquette.edu

Follow this and additional works at: https://epublications.marquette.edu/bioengin_fac

Part of the Biomedical Engineering and Bioengineering Commons

\section{Recommended Citation}

Garrison, M. Kevin; Ng, Alexander V.; and Schmit, Brian D., "Leg Sympathetic Response to Noxious Skin Stimuli is Similar in High and Low Level Human Spinal Cord Injury" (2008). Biomedical Engineering Faculty Research and Publications. 299.

https://epublications.marquette.edu/bioengin_fac/299 


\title{
Leg Sympathetic Response to Noxious Skin Stimuli Is Similar in High and Low Level Human Spinal Cord Injury
}

\author{
M. Kevin Garrison \\ Department of Biomedical Engineering, Marquette University \\ Milwaukee, WI \\ Alexander V. Ng \\ Program in Exercise Science, Marquette University \\ Milwaukee, WI \\ Brian D. Schmit \\ Department of Biomedical Engineering, Marquette University \\ Milwaukee, WI
}

\section{Abstract \\ Objective}

To determine if sympathetically mediated vasoconstriction in the lower extremities is injury-level dependent. Although sympathetic responses have been measured in the limbs of people with high and low level SCI using blood flow measurements, including Doppler ultrasound and venous plethysmography, a direct comparison between injury levels has not been made.

\section{Methods}

Volunteers with chronic SCI were grouped according to injury level. Above T6: high level $(H L, n=7)$, and T6 and below: low level $(L L, n=6)$. All 
NOT THE PUBLISHED VERSION; this is the author's final, peer-reviewed manuscript. The published version may be accessed by following the link in the citation at the bottom of the page.

subjects had complete motor and sensory loss. Leg arterial flows were recorded by venous occlusion plethysmography, and continuous heart rate and mean arterial pressure (MAP) were measured. The conditioning stimulus consisted of transcutaneous stimulation to the arch of the contralateral foot.

\section{Results}

$\mathrm{HL}$ and LL subjects demonstrated a significant decrease in arterial conductance during stimulation with no significant difference found between groups. As expected, only group HL demonstrated a significant increase in MAP.

\section{Conclusions}

These results support our hypothesis that local (leg) sympathetic responses are similar for both high and low level SCI.

\section{Significance}

While low level SCI does not typically present with autonomic dysreflexia, bouts of increased reflex sympathetic activity could have ramifications for metabolism as well as renal and motor system function.

Keywords: Vasoconstriction, conductance, blood pressure, autonomic dysreflexia

Go to:

\section{Introduction}

The purpose of this study was to compare the local (leg) sympathetically mediated responses produced in response to controlled noxious electrocutaneous stimuli in people with cervical and upper thoracic (T5 and above) versus mid to lower thoracic level (T6 to T12) spinal cord injury (SCI). Autonomic system abnormalities following SCI are responsible for altered cardiovascular, thermal, gastrointestinal, urinary, and reproductive systems regulation (Mathias and Bannister, 1999). For example, one of the relatively common clinical manifestations of abnormal autonomic reflexes in high level injuries is autonomic dysreflexia (AD). AD is characterized by paroxysmal hypertensive episodes induced by non-specific stimuli below the level of the lesion (Curt et al., 1997) and symptoms can be

Clinical Neurophysiology, Vol. 119, No. 2 (February 2008): pg. 466-474. DOI. This article is (C) Elsevier and permission has been granted for this version to appear in e-Publications@Marquette. Elsevier does not grant permission for this article to be further copied/distributed or hosted elsewhere without the express permission from Elsevier. 
triggered in $45-90 \%$ of individuals with quadriplegia or high paraplegia (Yarkony, 1994; Teasell et al., 2000). The most common stimuli for inducing $A D$ involve pain and sensory signals from the bowel and bladder (McKinley et al., 1999), and AD is often associated with the occurrence of pressure sores (Johnson et al., 1998) and chronic pain (Widerstrom-Noga et al., 2004). Early investigations of AD described a "mass reflex" in high level SCI during induced bladder distention with symptoms that included profound sweating, headache, and muscle spasms (Head and Riddoch, 1917). Because of the clinical significance of $A D$, much of the research on autonomic function in SCI has been focused on high level injuries.

The injury-level dependent nature of $A D$ is clear with occurrences reported almost exclusively in individuals with injuries at level T5 and above (Guttmann and Whitteridge, 1947; Frankel and Mathias, 1979; Mathias and Frankel, 1986; Somers, 2001) with one exception reported in an individual with a T10 injury (Gimovsky et al., 1985). Although individuals with injuries from T6-L2 rarely demonstrate a systemic pressor response to noxious stimuli, they typically have intact sympathetic reflexes as indicated by lower extremity cutaneous and muscular vasoconstriction (Cunningham et al., 1953; Wurster and Randall, 1975). A key difference is that these lower level injuries maintain descending control over the large splanchnic vascular beds and cardiac sympathetic outflow (Wurster and Randall, 1975; Karlsson, 1999a) that contribute to the pressure increase in people with higher level injuries. It is unknown, however, whether the magnitude of the local sympathetic response (decreased lower extremity peripheral conductance) is influenced by the level of spinal cord injury. Although the spinal systems that mediate the sympathetic reflexes in segments below the injury are expected to be similar in people with high and low level injuries, the number of intact segments above the level of testing, or distance from the injury, could influence the response through intraspinal pathways, which are the key regulators of sympathetic activity after injury (Tang et al., 2004; Schramm, 2006). An example of level-dependent sympathetic response has been shown in complete SCI where the sympathetic skin response to stimuli below the injury can vary depending on the stimulation site (Reitz et al., 2002).

Clinical Neurophysiology, Vol. 119, No. 2 (February 2008): pg. 466-474. DOI. This article is @ Elsevier and permission has been granted for this version to appear in e-Publications@Marquette. Elsevier does not grant permission for this article to be further copied/distributed or hosted elsewhere without the express permission from Elsevier. 
Because of the influence of sympathetic outflow on a number of physiologic systems besides the cardiovascular system, it is of interest to determine if people with lower level injuries exhibit similar decentralized sympathetic reflexes as those with higher level injuries. For example, an increase in renal sympathetic nerve activity (RSNA) accompanies $A D$ resulting in an increase in renal vascular resistance (Gao et al., 2002). However, RSNA is not always correlated with blood pressure changes in spinal rats (Hong et al., 1994), thus, it is possible that individuals with lower level SCI could have reflex RSNA from the lower thoracic segments without manifesting AD. Many of the deleterious effects of elevated sympathetic activity to the kidneys are known (Joles and Koomans, 2004) but the long term effects in SCI still need to be investigated. Another pathophysiologic process that could affect all levels of SCI is the observed changes in adipose metabolism due to increased bouts of sympathetic activity that results in increased glycerol release and possible contribution to insulin resistance (Karlsson, 1999b). Finally, the literature frequently reports increased muscle spasms as a symptom of AD (Head and Riddoch, 1917; Kewalramani, 1980; Mathias and Bannister, 1999; Abel et al., 2003). While the mechanisms of this motor-sympathetic association are not known, the potential confounding effect of sympathetic reflexes on spasms has implications for all levels of injury where spasticity often contributes to disability (Skold et al., 1999).

In this study we sought to provide evidence for the assumption that people with low level injuries have a similar magnitude of local sympathetic response to noxious stimuli as people with high level lesions, based on comparable peripheral and spinal plastic changes following SCI (Teasell et al., 2000). In order to test our hypothesis, we measured the sympathetic response to noxious stimuli in people with high and low level injuries using venous plethysmography and systemic blood pressure recordings. We predicted that the magnitude of the sympathetic mediated vasoconstriction would be comparable in both groups, consistent with an isolated sympathetic spinal reflex.

\section{Materials and Methods}

\section{Subjects}

Clinical Neurophysiology, Vol. 119, No. 2 (February 2008): pg. 466-474. DOI. This article is (C) Elsevier and permission has been granted for this version to appear in e-Publications@Marquette. Elsevier does not grant permission for this article to be further copied/distributed or hosted elsewhere without the express permission from Elsevier. 
Thirteen volunteers with SCI were recruited for participation in this study. All subjects were at least 2-years post injury and were classified as complete injuries (ASIA A). Six subjects had injuries below the T5 level and were classified as low-level (LL) subjects. The remaining seven subjects had injuries at $\mathrm{T} 5$ and above and were operationally defined as high-level (HL). Additional subject characteristics including individual injury level, age, gender, medications, and time since injury are listed in Table 1 . Subjects were not asked to alter their medication dosage or schedule prior to the experiments. None of the subjects were smokers and consumption of caffeine and alcohol was avoided prior to the experiment. Exclusion criteria included unhealed pressure sores, bladder or other infection, and hypertension. Informed consent was obtained from all subjects prior to participation in the study. The experimental protocol was approved by the Marquette University IRB and adhered to the principles of the Declaration of Helsinki.

\begin{tabular}{|c|c|c|c|c|c|c|c|c|}
\hline \multirow[b]{2}{*}{ Subject } & \multirow[b]{2}{*}{$\mid \begin{array}{c}\text { Neurological } \\
\text { level }\end{array}$} & \multirow[b]{2}{*}{$\begin{array}{c}\text { Age } \\
\text { (years) }\end{array}$} & \multirow[b]{2}{*}{\begin{tabular}{|c|}
$\begin{array}{c}\text { Duration } \\
\text { of SCI } \\
\text { (years) }\end{array}$ \\
\end{tabular}} & \multirow[b]{2}{*}{ Gender } & \multirow[b]{2}{*}{ Medications } & \multicolumn{3}{|c|}{ Baseline Data } \\
\hline & & & & & & $\begin{array}{c}\text { MAP } \\
(\mathrm{mmHg})\end{array}$ & \begin{tabular}{|c|} 
Conductance \\
$\left(\%\right.$ min $^{-}$ \\
$\left.1 \mathbf{m m H g}^{-1}\right)$ \\
\end{tabular} & $\begin{array}{c}\text { HR } \\
\text { (beats } \\
\text { min }^{-1} \text { ) }\end{array}$ \\
\hline LL1 & T8 & 43 & 24 & $M$ & Oxybutinin & 88 & 0.0306 & 82 \\
\hline LL2 & T6 & 39 & 13 & M & $\begin{array}{c}\text { Baclofen, } \\
\text { Oxybutinin }\end{array}$ & 105 & 0.0148 & 79 \\
\hline LL3 & T6 & 24 & 3 & $M$ & None & 99 & 0.0251 & 93 \\
\hline LL4 & T6 & 24 & 4 & M & $\begin{array}{l}\text { Oxybutinin, } \\
\text { Imiprimine }\end{array}$ & 75 & 0.0231 & 72 \\
\hline LL5 & T10 & 24 & 5 & $M$ & Oxybutinin & 73 & 0.0362 & 76 \\
\hline LL6 & T10 & 25 & 6 & $M$ & Baclofen & 73 & 0.0272 & 65 \\
\hline HL1 & $\mathrm{C7}$ & 29 & 10 & $M$ & Baclofen & 94 & 0.0114 & 61 \\
\hline HL2 & C7-8 & 30 & 4 & $M$ & Tolterodine & 69 & 0.0410 & 52 \\
\hline HL3 & C7-T1 & 20 & 2 & $\mathrm{~F}$ & Baclofen & 62 & 0.0561 & 61 \\
\hline HL4 & T3 & 44 & 5 & $M$ & Darvocet & 81 & 0.0110 & 60 \\
\hline HL5 & T3 & 49 & 8 & M & $\begin{array}{c}\text { Baclofen, } \\
\text { Oxybutinin, } \\
\text { Imiprimine }\end{array}$ & 79 & 0.0407 & 66 \\
\hline HL6 & C6-7 & 48 & 22 & $M$ & None & 57 & 0.0298 & 54 \\
\hline HL7 & C6-7 & 48 & 15 & $M$ & $\begin{array}{l}\text { Neurotin, } \\
\text { Percoset }\end{array}$ & 82 & 0.0708 & 52 \\
\hline
\end{tabular}

Table 1 Subject characteristics 


\section{Experimental Procedures}

Bladder volume was not controlled in the experiment but due to the prolonged immobilization of the experimental setup, some subjects self-catheterized before the experiment while the others had indwelling catheters. Subjects were seated in a semi-reclined position with both legs elevated to heart level and the feet were stabilized to prevent movement. Arterial flows of the right leg were recorded with a venous occlusion plethysmography system (EC6, D.E. Hokanson Inc, Bellevue, WA). The system consisted of a mercury-in-silastic strain gauge placed around the largest circumference of the calf. A venous occlusion cuff was placed around the thigh and connected to a rapid inflator set at $55 \mathrm{mmHg}$. The inflation duty cycle was controlled by a digital pulse from the computer, producing 8 seconds of inflation followed by 12 seconds of rest to allow for flow measures every 20 seconds. A second cuff was placed just proximal to the ankle and was manually inflated to $180 \mathrm{mmHg}$ for the duration of the experiment (Figure 1). A Finapres (Finapres 2300, Ohmeda, Englewood, CO) was used to continuously monitor blood pressure and heart rate during the experiments. The cuff transducer was secured around the middle phalanx of the third digit while the arm and hand was supported so that the hand was resting at heart level.

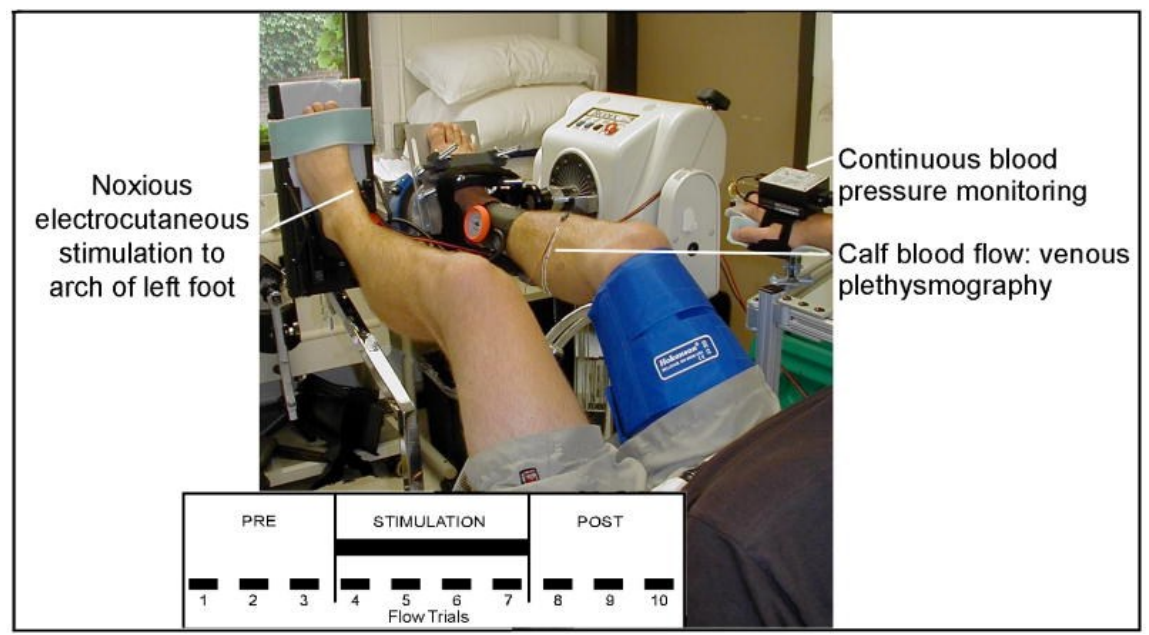

Figure 1 Experimental Setup

The subject's bilateral lower extremities were elevated and stabilized. Arterial calf flow was measured by venous occlusion plethysmography at 20 s intervals. Blood pressure was measured continuously. Sympathetic responses were produced by

Clinical Neurophysiology, Vol. 119, No. 2 (February 2008): pg. 466-474. DOI. This article is @ Elsevier and permission has been granted for this version to appear in e-Publications@Marquette. Elsevier does not grant permission for this article to be further copied/distributed or hosted elsewhere without the express permission from Elsevier. 
electrocutaneous stimulation to the arch of the foot. Inset shows experimental protocol: 90 s baseline, 90 s of stimulation, and a 90 s recovery phase.

To induce a sympathetic response, a noxious electrocutaneous stimulus was applied to the skin at the medial arch of the left foot. A pair of $\mathrm{Ag}-\mathrm{AgCl}, 2.5 \mathrm{~cm}$ square pregelled electrodes (Vermed, Bellows Falls, VT) were placed on the medial arch of the foot and were attached to a Digitimer stimulator (Model DS7A, Digitimer Ltd, Hertfordshire, England). A continuous electrical stimulus ( $25 \mathrm{~Hz}$, $40 \mathrm{~mA}, 1 \mathrm{~ms}$ pulsewidth) was applied to the electrodes for 90 s during the conditioning phase. The experimental design consisted of a 90 second baseline phase, 90 seconds of stimulation, and a 90 second recovery phase.

\section{Data Acquisition and Analysis}

Control of the stimulator and plethysmography pump was implemented using custom LabVIEW (National Instruments, Austin, TX) software on a PC. Blood pressure and leg volume signals were low pass filtered at $450 \mathrm{~Hz}$ before being sampled at $1000 \mathrm{~Hz}(6071 \mathrm{E} \mathrm{A} / \mathrm{D}$ board, National Instruments, Austin, TX) using the same computer system.

Offline processing of the blood pressure and leg volume signals included $10 \mathrm{~Hz}$ low pass filtering with a $4^{\text {th }}$ order, zero delay, Butterworth filter (butter/filtfilt Matlab command; Mathworks, Natick, MA). An event detection algorithm was then used to identify the systolic and diastolic deflections. Pulse pressure (systolic-diastolic blood pressure) and mean arterial pressure [(systolic-diastolic)/ $3+$ diastolic] were calculated and used as dependent variables. Arterial

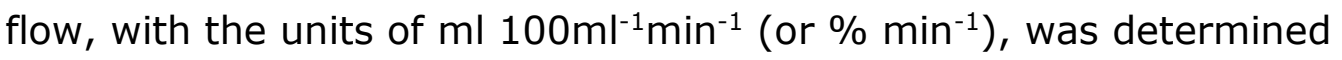
by calculating the slope of the volume curves during the middle 6 seconds of each 8 -second inflation period. The flow was divided by the mean arterial pressure (averaged over the corresponding time interval) to provide the arterial conductance during each 6-second window of time. The first flow values were discarded to account for cuff settling, leaving 3 measures of baseline conductance, 4 measures during the stimulus and 3 measures after the stimulation was terminated.

Clinical Neurophysiology, Vol. 119, No. 2 (February 2008): pg. 466-474. DOI. This article is @ Elsevier and permission has been granted for this version to appear in e-Publications@Marquette. Elsevier does not grant permission for this article to be further copied/distributed or hosted elsewhere without the express permission from Elsevier. 
NOT THE PUBLISHED VERSION; this is the author's final, peer-reviewed manuscript. The published version may be accessed by following the link in the citation at the bottom of the page.

\section{Statistics}

Because baseline pressure and conductance values varied widely between subjects, it was necessary to normalize the values before performing statistical analysis. First, the mean values of each phase were determined. The stimulation and recovery phases were then normalized by the mean baseline value. The change in mean arterial pressure, pulse pressure, heart rate, and conductance was calculated and compared for each phase using mixed design 2-way ANOVA's (Group (2) $\times$ Phase (3)), a=0.05. A Huynh-Feldt correction was used to account for possible violations of sphericity. Univariant analysis was applied when group-phase interactions occurred and least significant differences were calculated for pairwise comparisons between all phases.

An equivalence test was performed for the conductance data as described by KA Garrett.(Garrett, 1997). The practical significance (tolerance) levels were set at $50 \%$ of the change in conductance reported in similar studies investigating the cardiovascular reflex to cutaneous stimuli in SCI (Cunningham et al., 1953; Corbett et al., 1971a, b; Corbett et al., 1975).

\section{Results}

The sympathetic response to noxious cutaneous stimulation was robust and demonstrated a strong level dependence for the change in mean arterial pressure (MAP). Typical MAP and arterial flow responses can be seen in Figures 2 and and33 for subjects with high level and low level injures respectively. The ANOVA for MAP showed a predictable group*phase interaction $(p=0.008)$. Univariate analysis by group resulted in a main effect for phase in the HL group only $(p=0.001)$. The noxious stimulation produced a significant change from baseline values with a mean peak change of $12.2 \mathrm{mmHg}$ (SD= 6.9) in the HL group. Pairwise comparisons showed that the significant increase in MAP continued into the recovery phase (Figure 4A). The LL group showed a mean peak change of $1.2 \mathrm{mmHg}(\mathrm{SD}=3.9)$.

Clinical Neurophysiology, Vol. 119, No. 2 (February 2008): pg. 466-474. DOI. This article is (c) Elsevier and permission has been granted for this version to appear in e-Publications@Marquette. Elsevier does not grant permission for this article to be further copied/distributed or hosted elsewhere without the express permission from Elsevier. 
NOT THE PUBLISHED VERSION; this is the author's final, peer-reviewed manuscript. The published version may be accessed by following the link in the citation at the bottom of the page.

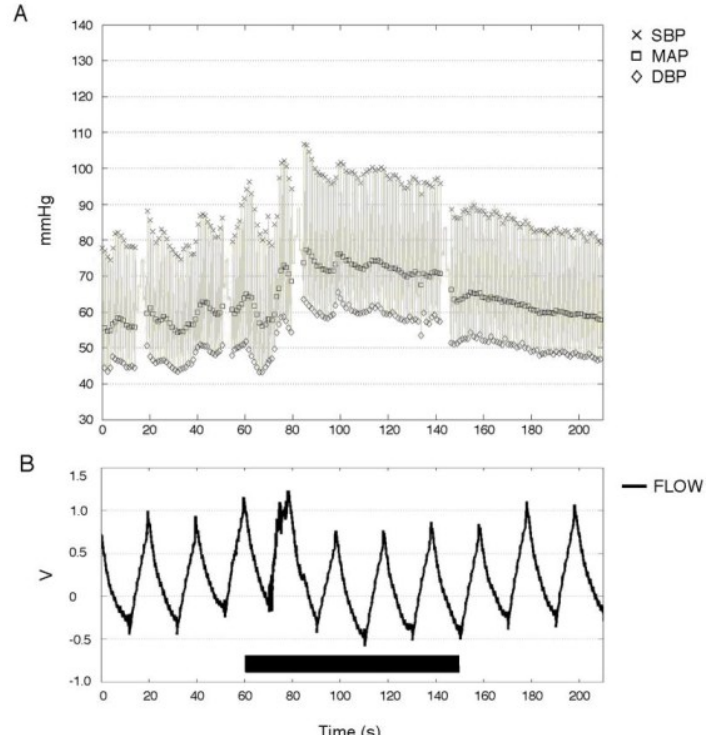

\section{Figure 2 High Level Injury Representative Data}

Representative data from HL6 during noxious cutaneous stimulation to the left foot. Absolute systolic (SBP), diastolic (DBP), and mean arterial pressure (MAP) and the calf flow curves are plotted over the duration of the experiment. The black bar denotes the stimulation phase. (A) Blood pressure response shows rapid rise and gradual decline even while the stimulation continues. (B) Calf blood flow from the right leg follows a similar time course to blood pressure. Movement artifact due to a muscle spasm is recorded in the 4 th trial.

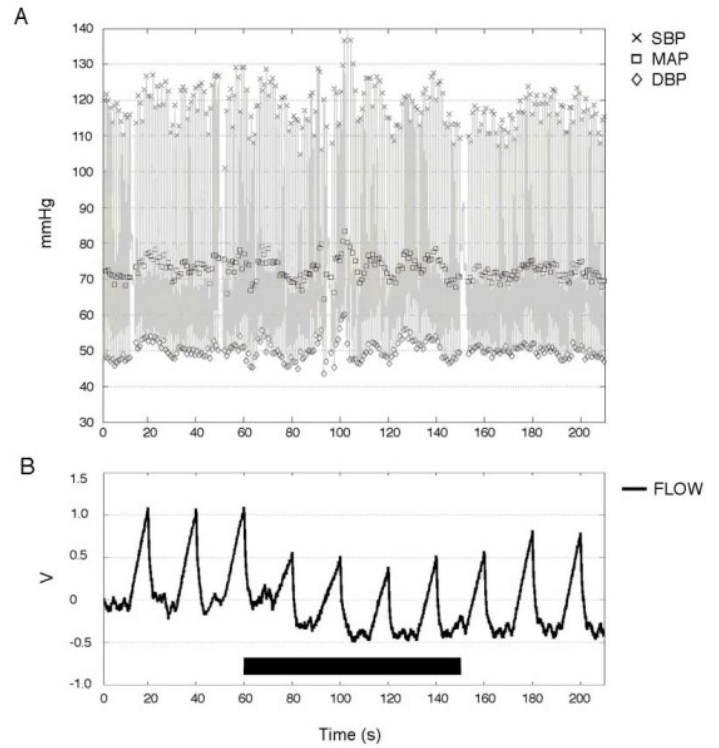

\section{Figure 3 Low Level Injury Representative Data}

Representative data from LL4 during noxious cutaneous stimulation to the left foot. (A) Note there is no change in blood pressure due to the noxious stimulation but (B) right calf blood flow is reduced at the onset of stimulation with some recovery

Clinical Neurophysiology, Vol. 119, No. 2 (February 2008): pg. 466-474. DOI. This article is @ Elsevier and permission has been granted for this version to appear in e-Publications@Marquette. Elsevier does not grant permission for this article to be further copied/distributed or hosted elsewhere without the express permission from Elsevier. 
NOT THE PUBLISHED VERSION; this is the author's final, peer-reviewed manuscript. The published version may be accessed by following the link in the citation at the bottom of the page.

occurring during stimulation (black bar inset), and near full recovery in the post stimulation phase.

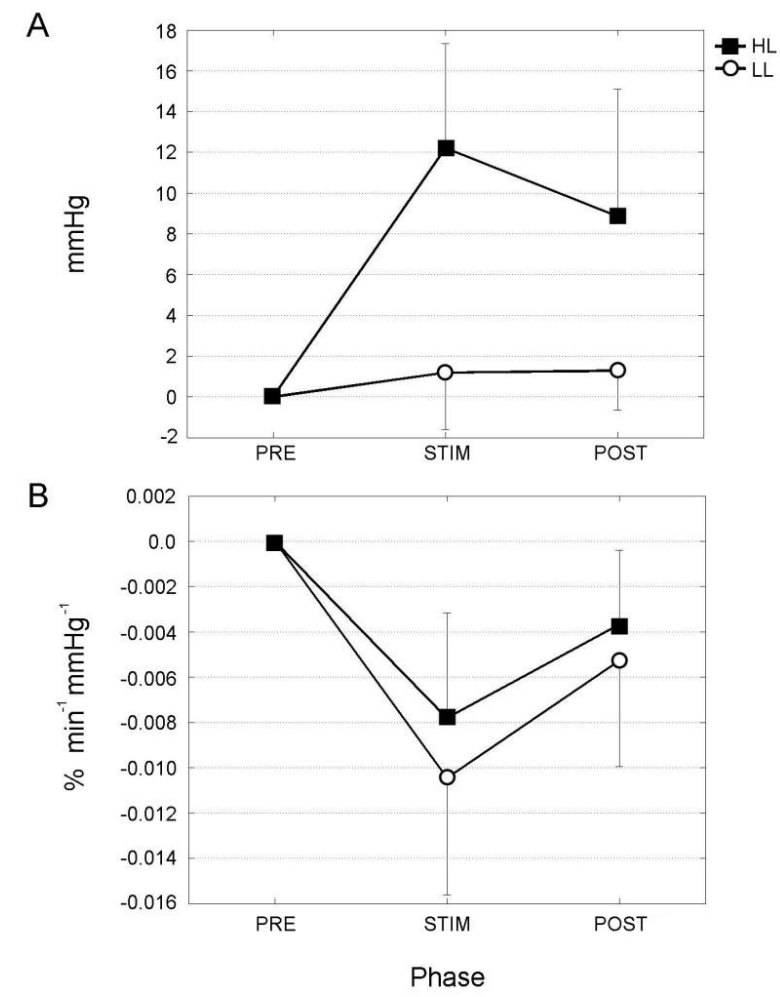

\section{Figure 4 Normalized Mean Arterial Pressure and Conductance: Group Data}

Normalized mean arterial pressure (MAP) and conductance values with $95 \%$ confidence intervals are plotted by phase. (A) The change in MAP in the HL group was significant $(p=0.001)$ during the stimulation phase and remained elevated into the recovery phase. (B) Conductance for both groups decreased significantly $(p<0.001)$ during the stimulation phase with no difference found based on level of injury.

The change in lower extremity arterial conductance was also robust, but no level dependence was demonstrated. For conductance, a significant main effect was only found for phase (two factor ANOVA, $p<0.001)$. No difference was found between HL and LL with both groups showing a significant change in conductance during stimulation with the mean peak decrease for $\mathrm{HL}$ of $0.0078 \% \mathrm{~min}^{-1} \mathrm{mmHg}^{-1}$ (SD= $0.0063)$ and LL $0.0105 \% \mathrm{~min}^{-1} \mathrm{mmHg}^{-1}(\mathrm{SD}=0.0064)$. Pairwise comparisons demonstrated a significant difference in both the stimulation and recovery phases from baseline values. (Figure 4B). Although the ANOVA showed no difference between groups, a statistical equivalence test was performed to determine whether the

Clinical Neurophysiology, Vol. 119, No. 2 (February 2008): pg. 466-474. DOI. This article is @ Elsevier and permission has been granted for this version to appear in e-Publications@Marquette. Elsevier does not grant permission for this article to be further copied/distributed or hosted elsewhere without the express permission from Elsevier. 
conductance changes could be considered equivalent between the HL and LL groups. The 95\% confidence interval included zero so the null hypothesis of equal means was not rejected. Conversely, the $95 \%$ confidence interval did not extend past the tolerance, \pm 0.0065 , so the equivalence null hypothesis (unequal means) was rejected. As a result, we concluded that the conductance change in both groups was equal during the stimulation phase.

The change in pulse pressure (PP) showed a main effect for phase only $(p=0.043)$. No significance was found for group $(p=0.057)$ because of the lack of statistical power. As a result, univariate analyses by group were performed and a main effect was found for phase in the HL group $(p=0.042)$. In contrast to MAP, pairwise comparisons showed an increase in PP during the stimulation phase only. The mean peak increase in PP for $\mathrm{HL}$ was $5.83 \mathrm{mmHg}$ ( $\mathrm{SD}=$ 4.31) while $\mathrm{LL}$ increased $0.95 \mathrm{mmHg}(\mathrm{SD}=4.21)$. (Figure $5 \mathrm{~A})$
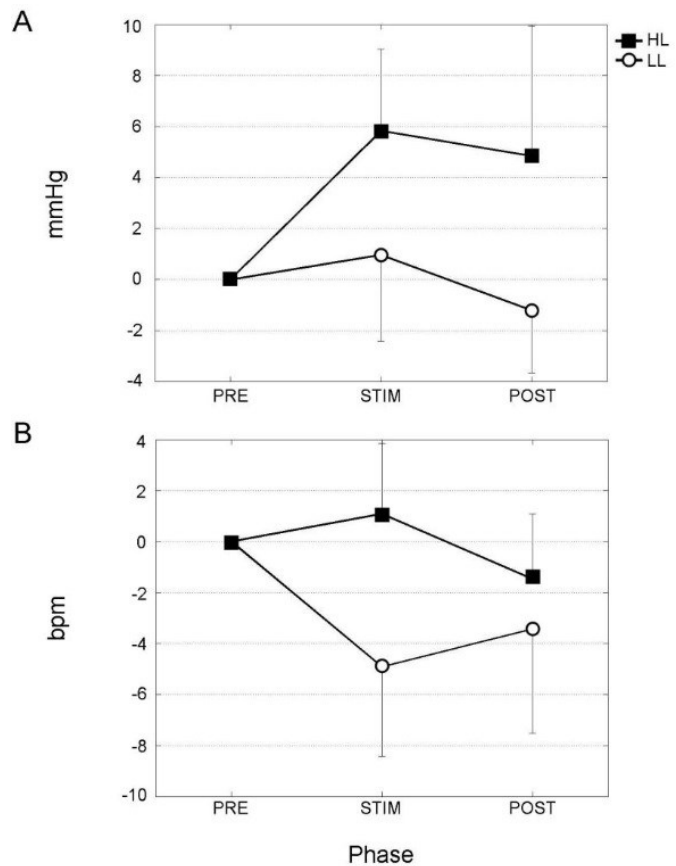

Figure 5 Normalized Pulse Pressure and Heart Rate: Group Data Normalized heart rate (HR) and pulse pressure with 95\% confidence intervals are plotted across phases. (A) The significant increase in MAP was accompanied by an increase in pulse pressure in the HL group $(p=0.042)$. (B) The heart rate changes were less robust with only the LL group showing a significant decrease $(p=0.047)$ during stimulation. 
The heart rate response to the cutaneous stimulation was mixed with a group*phase interaction $(p=0.037)$ occurring. Univariate analysis showed a main effect for phase in the LL group $(p=0.047)$. The mean decrease during stimulation was $4.9 \mathrm{bpm}(\mathrm{SD}=4.4)$ for the $\mathrm{LL}$ group while the HL group showed a slight increase in HR of $1.1 \mathrm{bpm}$ $(\mathrm{SD}=3.7)$. (Figure $5 \mathrm{~B})$.

\section{Discussion}

The main findings in our study were as follows. (i) Lower extremity conductance changes were similar between both high and low level injuries for the reflex sympathetic responses obtained through noxious electrocutaneous stimulation. This suggests that both high and low level injuries experience similar sympathetic reflex responses at the lower extremity level during modest sympathetic events. (ii) Only the high level group demonstrated a significant increase in mean arterial pressure. This is consistent with findings of other studies and, given similar changes in lower extremity vasoconstriction, supports the idea that the loss of descending control of the splanchnic vasculature plays a dominant role in blood pressure elevation during AD. (iii) The change in MAP seen in the high level group was accompanied by an increase in pulse pressure that is suggestive of inotropic effects from reflex excitation of cardiac sympathetic fibers in parallel with splanchnic and peripheral vasoconstriction.

\section{Conductance Changes}

The magnitude and time course of the vascular conductance changes were similar between HL and LL groups. Although we observed a large range of conductance and pressor changes among individuals, the magnitude of the changes was similar to those reported by Corbett et al. (Corbett et al., 1971b, a; Corbett et al., 1975), who used cutaneous stimuli and bladder percussion to induce sympathetic reflexes. Individual differences result in large variability, and small increases in blood flow have even been reported in some subjects (Corbett et al., 1971a); however, we observed no increases in blood flow (increased conductance) for any of the subjects in the current study. A possible limitation of the current study is the lack of

Clinical Neurophysiology, Vol. 119, No. 2 (February 2008): pg. 466-474. DOI. This article is (C) Elsevier and permission has been granted for this version to appear in e-Publications@Marquette. Elsevier does not grant permission for this article to be further copied/distributed or hosted elsewhere without the express permission from Elsevier. 
age and BMI matching. While the mean ages were different ( $L L=30$ yrs, $\mathrm{HL}=38 \mathrm{yrs}$ ), the data were normalized to reduce the effect of age and BMI on autonomic tone. In addition, there was no significant difference between groups for baseline conductance measures. Overall, the equivalent conductance changes in the HL and LL groups support our hypothesis that local reflex changes are similar, regardless of level of injury.

\section{Pressure Changes}

An injury-level dependent pressor response was found, as expected, with the HL group, who showed increased MAP. Although modest, the pressor responses were of similar magnitude to other studies of bladder percussion and cutaneous stimulation (Corbett et al., 1975; Karlsson et al., 1998). As a result, our findings of similar conductance changes for HL and LL subjects should be considered in the context of the modest pressure response and may not apply to cases of full AD. Additionally, none of our HL subjects reported a headache or other symptoms such as nasal stuffiness, profuse sweating, or flushing during the experiments. The most common report was of a vague feeling of a need to void their bladder. Clinically it is worth noting that these local sympathetic events may be common, and often go unnoticed in a manner similar to "silent dysreflexia" (Kirshblum et al., 2002).

The noted increase in pulse pressure amplitude in the HL group is consistent with the occurrence of increased cardiac sympathetic activity as part of the reflex response to the noxious stimulus. An increase in peripheral vascular resistance due to constriction of the large splanchnic beds would be expected to cause increases in both systolic and diastolic blood pressure (Wurster and Randall, 1975). Instead, we saw a greater increase in systolic than diastolic pressure, resulting in an increase in pulse pressure, that we attributed to a sympathetically mediated increased cardiac contractility. This sympathetic outflow would also be expected to result in increased heart rate. However, vagal innervation is typically intact post SCI, and it may counter the chronotropic effects, resulting in the small and clinically insignificant change in HR that we saw in the majority of our subjects.

Clinical Neurophysiology, Vol. 119, No. 2 (February 2008): pg. 466-474. DOI. This article is @ Elsevier and permission has been granted for this version to appear in e-Publications@Marquette. Elsevier does not grant permission for this article to be further copied/distributed or hosted elsewhere without the express permission from Elsevier. 
The role of the baroreflex on the observed heart rate and pressure changes warrants some consideration. In this study, the LL group would be expected to have a normal baroreflex that consists of a delicate balance between withdrawal of sympathetic activity (T1-4) and an increase in parasympathetic activity (vagus nerve) in response to pressure increases. The HL group can be divided into two categories of baroreflex dysfunction. With SCI above the T1-4 level, the sympathetic arm of the baroreflex is lost; however, sympathetic outflow is still likely as part of a generalized sympathetic response to noxious stimuli. In contrast, those with injury to the upper thoracic levels are at risk for a total loss of sympathetic outflow which could result in severe bradycardia due to uncontested vagal activity.

\section{Implications}

Our results support Frankel's concept of AD being a "sympathetic storm" (Frankel and Mathias, 1979) that targets lower extremity and splanchnic vascular beds as well as the heart, depending on the degree of lost descending control corresponding to the location of the injury. Although a lack of inhibition from higher centers is prerequisite to the development of AD (Curt et al., 1996), a time dependent reorganization of the neural circuitry and changes in peripheral receptor sensitivity contribute to this pathologic reflex (Krassioukov et al., 2002; Weaver et al., 2002). In animal models, plasticity has been documented in many components of the sympathetic reflex arc including small diameter primary afferents (Krenz et al., 1999; Weaver et al., 2001) and sympathetic preganglionic neurons (Krassioukov and Weaver, 1996), and these changes correspond to the emergence (Krassioukov and Weaver, 1995) and severity (Krenz et al., 1999) of AD. All of the subjects in the current study were at least 2-years post injury, placing them in a chronic state where any plastic changes in the sympathetic reflex pathways would have probably already occurred. It is unlikely that the same sensitivity exists in acute injury, however, the progression of sympathetic reflex adaptation is unknown in human SCI.

In addition to neuroplasticity at the spinal level, peripheral changes likely contributed to the decrease in arterial conductance observed in the current study. Peripheral noradrenaline

Clinical Neurophysiology, Vol. 119, No. 2 (February 2008): pg. 466-474. DOI. This article is (C) Elsevier and permission has been granted for this version to appear in e-Publications@Marquette. Elsevier does not grant permission for this article to be further copied/distributed or hosted elsewhere without the express permission from Elsevier. 
supersensitivity has been documented in chronic human SCI (Mathias et al., 1976; Arnold et al., 1995), and there is additional evidence for more noradrenaline release per impulse (Gao et al., 2002) as well as an increased number of peripheral receptors post SCI (Velasco et al., 1997). In rats, approximately $50 \%$ of the $A D$ pressor response can be attributed to vascular hyper-responsiveness (Collins and DiCarlo, 2002). At present it is difficult to determine the relative contribution of increased sympathetic outflow and peripheral noradrenaline supersensitivity on conductance changes in the current study.

The effects of altered sympathetic function in the lower segments of the spinal cord are not fully known, however, they could have implications for $H L$ and $L L$ injuries alike based on the findings of this study. The modest sympathetic responses we documented may occur on a regular basis and go undetected, yet it is possible that they could have deleterious effects on metabolism, renal function, and muscle spasms. The results of the current skin stimulation experiments provide evidence for a non-invasive, reproducible method to generate transient local sympathetic reflexes in a laboratory environment. Future studies can build on these findings by examining the effects of sympathetic activity on motor reflexes in both high and low level SCI.

\section{Acknowledgments}

This study was funded in part by NIH Grant NS40901 and a Promotion of Doctoral Studies scholarship from the Foundation for Physical Therapy.

\section{Footnotes}

Publisher's Disclaimer: This is a PDF file of an unedited manuscript that has been accepted for publication. As a service to our customers we are providing this early version of the manuscript. The manuscript will undergo copyediting, typesetting, and review of the resulting proof before it is published in its final citable form. Please note that during the production process errors may be discovered which could affect the content, and all legal disclaimers that apply to the journal pertain.

Clinical Neurophysiology, Vol. 119, No. 2 (February 2008): pg. 466-474. DOI. This article is @ Elsevier and permission has been granted for this version to appear in e-Publications@Marquette. Elsevier does not grant permission for this article to be further copied/distributed or hosted elsewhere without the express permission from Elsevier. 
NOT THE PUBLISHED VERSION; this is the author's final, peer-reviewed manuscript. The published version may be accessed by following the link in the citation at the bottom of the page.

\section{References}

Abel R, Cerrel Bazo HA, Kluger PJ, Selmi F, Meiners T, Vaccaro A, Ditunno J, Gerner $\mathrm{HJ}$. Management of degenerative changes and stenosis of the lumbar spinal canal secondary to cervical spinal cord injury. Spinal Cord. 2003;41(4):211-219.

Arnold JM, Feng QP, Delaney GA, Teasell RW. Autonomic dysreflexia in tetraplegic patients: evidence for alpha-adrenoceptor hyperresponsiveness. Clinical Autonomic Research. 1995;5(5):267-270.

Collins HL, DiCarlo SE. Acute exercise reduces the response to colon distension in T(5) spinal rats. American Journal of Physiology - Heart \& Circulatory Physiology. 2002;282(4):H1566-1570.

Corbett JL, Frankel HL, Harris PJ. Cardiovascular reflex responses to cutaneous and visceral stimuli in spinal man. Journal of Physiology. 1971a;215(2):395-409.

Corbett JL, Frankel HL, Harris PJ. Cardiovascular changes associated with skeletal muscle spasm in tetraplegic man. Journal of Physiology. 1971b;215(2):381-393.

Corbett JL, Debarge O, Frankel HL, Mathias C. Cardiovascular responses in tetraplegic man to muscle spasm, bladder percussion and head-up tilt. Clinical \& Experimental Pharmacology \& Physiology. 1975;(Suppl2): 189-193.

Cunningham DJ, Guttmann L, Whitteridge D, Wyndham CH. Cardiovascular responses to bladder distension in paraplegic patients. Journal of Physiology. 1953;121(3):581-592.

Curt A, Weinhardt C, Dietz V. Significance of sympathetic skin response in the assessment of autonomic failure in patients with spinal cord injury. Journal of the Autonomic Nervous System. 1996;61(2):175-180.

Curt A, Nitsche B, Rodic B, Schurch B, Dietz V. Assessment of autonomic dysreflexia in patients with spinal cord injury. Journal of Neurology, Neurosurgery \& Psychiatry. 1997;62(5):473-477.

Frankel HL, Mathias CJ. Cardiovascular aspects of autonomic dysreflexia since Guttmann and Whitteridge (1947) Paraplegia. 1979;17(1):46-51.

Clinical Neurophysiology, Vol. 119, No. 2 (February 2008): pg. 466-474. DOI. This article is @ Elsevier and permission has been granted for this version to appear in e-Publications@Marquette. Elsevier does not grant permission for this article to be further copied/distributed or hosted elsewhere without the express permission from Elsevier. 
NOT THE PUBLISHED VERSION; this is the author's final, peer-reviewed manuscript. The published version may be accessed by following the link in the citation at the bottom of the page.

Gao SA, Ambring A, Lambert G, Karlsson AK. Autonomic control of the heart and renal vascular bed during autonomic dysreflexia in high spinal cord injury. Clinical Autonomic Research. 2002;12(6):457-464.

Garrett KA. Use of Statistical Tests of Equivalence (Bioequivalence Tests) in Plant Pathology. Phytopathology. 1997;87(4):372-374.

Gimovsky ML, Ojeda A, Ozaki R, Zerne S. Management of autonomic hyperreflexia associated with a low thoracic spinal cord lesion. American Journal of Obstetrics \& Gynecology. 1985;153(2):223-224.

Guttmann L, Whitteridge D. Effects of bladder distension on autonomic mechanisms after spinal cord injury. Brain. 1947;70:361-404.

Head $\mathrm{H}$, Riddoch $\mathrm{G}$. The automatic bladder, excessive sweating and some other reflex conditions, in gross injuries of the spinal cord. Brain. $1917 ; 40: 188-263$.

Hong Y, Cechetto DF, Weaver LC. Spinal cord regulation of sympathetic activity in intact and spinal rats. American Journal of Physiology. 1994;266(4 Pt 2):H1485-1493.

Johnson RL, Gerhart KA, McCray J, Menconi JC, Whiteneck GG. Secondary conditions following spinal cord injury in a population-based sample. Spinal Cord. 1998;36(1):45-50.

Joles JA, Koomans HA. Causes and consequences of increased sympathetic activity in renal disease. Hypertension. 2004;43(4):699-706.

Karlsson AK, Friberg P, Lonnroth P, Sullivan L, Elam M. Regional sympathetic function in high spinal cord injury during mental stress and autonomic dysreflexia. Brain. 1998;121(Pt 9):1711-1719.

Karlsson AK. Autonomic dysreflexia. Spinal Cord. 1999a;37(6):383-391.

Karlsson AK. Insulin resistance and sympathetic function in high spinal cord injury. Spinal Cord. 1999b;37(7):494-500.

Kewalramani LS. Autonomic dysreflexia in traumatic myelopathy. American Journal of Physical Medicine. 1980;59(1):1-21.

Kirshblum S, House J, O'Connor K. Silent autonomic dysreflexia during a routine bowel program in persons with traumatic spinal cord injury: A

Clinical Neurophysiology, Vol. 119, No. 2 (February 2008): pg. 466-474. DOI. This article is @ Elsevier and permission has been granted for this version to appear in e-Publications@Marquette. Elsevier does not grant permission for this article to be further copied/distributed or hosted elsewhere without the express permission from Elsevier. 
NOT THE PUBLISHED VERSION; this is the author's final, peer-reviewed manuscript. The published version may be accessed by following the link in the citation at the bottom of the page.

preliminary study. Archives of Physical Medicine and Rehabilitation. 2002;83(12):1774-1776.

Krassioukov AV, Weaver LC. Reflex and morphological changes in spinal preganglionic neurons after cord injury in rats. Clinical \& Experimental Hypertension. 1995;17(12):361-373.

Krassioukov AV, Weaver LC. Morphological changes in sympathetic preganglionic neurons after spinal cord injury in rats. Neuroscience. $1996 ; 70(1): 211-225$.

Krassioukov AV, Johns DG, Schramm LP. Sensitivity of sympathetically correlated spinal interneurons, renal sympathetic nerve activity, and arterial pressure to somatic and visceral stimuli after chronic spinal injury. Journal of Neurotrauma. 2002;19(12):1521-1529.

Krenz NR, Meakin SO, Krassioukov AV, Weaver LC. Neutralizing intraspinal nerve growth factor blocks autonomic dysreflexia caused by spinal cord injury. Journal of Neuroscience. 1999;19(17):7405-7414.

Mathias C, Bannister R. Autonomic disturbances in spinal cord lesions. In: Mathias C, Bannister R, editors. Autonomic failure : a textbook of clinical disorders of the autonomic nervous system. 4. Oxford: Oxford University Press; 1999. pp. 494-513.

Mathias CJ, Christensen NJ, Corbett JL, Frankel HL, Spalding JM. Plasma catecholamines during paroxysmal neurogenic hypertension in quadriplegic man. Circ Res. 1976;39(2):204-208.

Mathias CJ, Frankel HL. The neurological and hormonal control of blood vessels and heart in spinal man. Journal of the Autonomic Nervous System Supplement. 1986:457-464.

McKinley WO, Jackson AB, Cardenas DD, DeVivo MJ. Long-term medical complications after traumatic spinal cord injury: a regional model systems analysis. Archives of Physical Medicine \& Rehabilitation. 1999;80(11): 1402-1410.

Reitz A, Schmid DM, Curt A, Knapp PA, Schurch B. Sympathetic sudomotor skin activity in human after complete spinal cord injury. Autonomic Neuroscience-Basic \& Clinical. 2002;102(12):78-84.

Clinical Neurophysiology, Vol. 119, No. 2 (February 2008): pg. 466-474. DOI. This article is @ Elsevier and permission has been granted for this version to appear in e-Publications@Marquette. Elsevier does not grant permission for this article to be further copied/distributed or hosted elsewhere without the express permission from Elsevier. 
NOT THE PUBLISHED VERSION; this is the author's final, peer-reviewed manuscript. The published version may be accessed by following the link in the citation at the bottom of the page.

Schramm LP. Spinal sympathetic interneurons: their identification and roles after spinal cord injury. Prog Brain Res. 2006;152:27-37.

Skold C, Levi R, Seiger A. Spasticity after traumatic spinal cord injury: nature, severity, and location. Archives of Physical Medicine \& Rehabilitation. 1999;80(12): 1548-1557.

Somers MF. Spinal cord injury:functional rehabilitation. 2. Upper Saddle River: Prentice-Hall, Inc.; 2001.

Sommers DK. Paroxysmal neurogenic hypertension and its prevention in patients with cervical spinal cord lesions. South African Medical Journal. Suid Afrikaanse Tydskrif Vir Geneeskunde. 1979;56(1):14-18.

Tang X, Neckel ND, Schramm LP. Spinal interneurons infected by renal injection of pseudorabies virus in the rat. Brain Res. 2004;1004(12):1-7.

Teasell RW, Arnold JM, Krassioukov A, Delaney GA. Cardiovascular consequences of loss of supraspinal control of the sympathetic nervous system after spinal cord injury. Archives of Physical Medicine \& Rehabilitation. 2000;81(4):506-516.

Velasco M, Gomez J, Blanco M, Rodriguez I. The cold pressor test: pharmacological and therapeutic aspects. American Journal of Therapeutics. 1997;4(1):34-38.

Weaver LC, Verghese P, Bruce JC, Fehlings MG, Krenz NR, Marsh DR. Autonomic dysreflexia and primary afferent sprouting after clipcompression injury of the rat spinal cord. Journal of Neurotrauma. 2001;18(10):1107-1119.

Weaver LC, Marsh DR, Gris D, Meakin SO, Dekaban GA. Central mechanisms for autonomic dysreflexia after spinal cord injury. Progress in Brain Research. 2002;137:83-95.

Widerstrom-Noga E, Cruz-Almeida Y, Krassioukov A. Is there a relationship between chronic pain and autonomic dysreflexia in persons with cervical spinal cord injury? J Neurotrauma. 2004;21(2):195-204.

Wurster RD, Randall WC. Cardiovascular responses to bladder distension in patients with spinal transection. American Journal of Physiology. $1975 ; 228(4): 1288-1292$.

Clinical Neurophysiology, Vol. 119, No. 2 (February 2008): pg. 466-474. DOI. This article is @ Elsevier and permission has been granted for this version to appear in e-Publications@Marquette. Elsevier does not grant permission for this article to be further copied/distributed or hosted elsewhere without the express permission from Elsevier. 
NOT THE PUBLISHED VERSION; this is the author's final, peer-reviewed manuscript. The published version may be accessed by following the link in the citation at the bottom of the page.

Yarkony GM. Medical and Physical Complications of Spinal Cord Injury. In: Yarkony GM, editor. Spinal Cord Injury: Medical Management and Rehabilitation. Gaithersburg: Aspen Publishers, Inc.; 1994. 